\title{
MITÄ POTILAS VOI TIETÄÄ? POTILAAN TIEDOLLISIIN OIKEUKSIIN ORIENTOITUMINEN LÄÄKÄRIN VASTAANOTOLLA
}

\begin{abstract}
Artikkelissa tarkastellaan lä̈̈ärin ja potilaan tiedollisten asemien rakentumista vastaanoton aloitusjaksossa eli käynnin syyn kertomisen ja vastaanottamisen vaiheessa. Tarkastelemme potilaiden kahta erilaista tapaa esittää diagnostinen arvelu osana käynnin syyn kuvausta. Vertaamme näiden tapojen seuraamuksellisuutta vuorovaikutukselle subteessa käynnin syyn kuvauksen perustyyppiin, jossa potilas kertoo vain oireet. Tulokset osoittavat, että potilaiden vuorovaikutuksen käytänteet vastaanoton alussa objaavat sitä, milloin ja miten lääkürit nostavat potilaan tiedollisen aseman keskustelussa käsiteltäväksi ja miten he subtautuvat potilaan oikeuteen hallita lä̈̈ketieteellistä tietoa. Keskustelemme myös siitä, miten potilaat voivat osallistua vastaanoton tehtävän ja toimijoiden tiedollisten oikeuksien mä̈rittelyyn. Tulokset avaavat mahdollisuuksia potilaan osallistumismahdollisuuksien muutoksia kartoittavalle jatkotutkimukselle. Tutkimuksen aineistona on 86 potilaan videoidut vastaanotot perusterveydenhuollosta. Metodina on keskustelunanalyysi.
\end{abstract}

Potilaan ja lääkärin näkökulmien erillisyys ja potilaan vähäisten osallistumismahdollisuuksien korostaminen on nostettu usein esiin lääkärin ja potilaan välisen vuorovaikutuksen tutkimuksessa: lääkärin ja potilaan roolien epäsymmetrian on nähty johtavan epätasavertaiseen institutionaaliseen suhteeseen sekä ristiriitaisiin tavoitteisiin osapuolten välillä (Barry, Stevenson, Britten, Barber \& Bradley 2001; Mishler 1984). Potilaan ja lääkärin välisen kasvokkaisen vuorovaikutuksen tutkimus on tuonut uusia näkökulmia tähän keskusteluun (Collins, Britten, Ruusuvuori \& Thompson 2007; Heritage \& Maynard 2006; Ruusuvuori 2000). Muiden muassa Stivers (2007; 2002a) on tutkinut potilaiden vuorovaikutuksen käytänteitä, joilla he ohjaavat ja jopa painostavat lääkäriä tiettyyn hoitopäätökseen.

Toisaalta, lääkäreiden vuorovaikutuksen tavat voivat rajoittaa tai parantaa potilaan mahdollisuuksia tuoda ajatuksiaan ja näkökulmiaan esille vastaanotolla (ks. esim. Robinson 2001). Potilaiden on todettu tavallisesti pidättäytyvän lääkärin tiedollisten oikeuksien piiriin kuuluvista tehtävistä, kuten diagnoosiehdotusten ja hoitopäätösten esittämisestä vastaanotolla (Drew 2006; Heritage \& Robinson 2006; Gill 1998; vrt. Raevaara 2000). Lääkärin ja poti- 
laan välisen suhteen ja heidän tiedollisten asemiensa epätasavertaisuus on siis vastaanottovuorovaikutuksessa näkyvästi läsnä.

Lääkäri-/potilaskeskeisyys on yksi käsitepari, jonka avulla on tarkasteltu osapuolten tapoja ja mahdollisuuksia osallistua vastaanottovuorovaikutuksen kulkuun. Potilaskeskeisessä työtavassa pyritään antamaan potilaalle tilaa ajatusten ja kokemusten esiin tuomiselle vastaanotolla ja lisäämään potilaan mahdollisuuksia osallistua itseään koskevaan keskusteluun ja päätöksentekoon terveydenhuollossa, millä on myönteisiä seurauksia paitsi potilastyytyväisyydelle myös hoitoon sitoutumiselle ja hoitotulosten saavuttamiselle (Robinson \& Heritage 2006; Barry ym. 2001). Potilaskeskeisyyden käsite ei kuitenkaan ole selkeästi määriteltävissä eikä potilaskeskeisyyden määrän tai toteutumisen mittaaminen yksiselitteistä (Mead \& Bower 2000; Collins ym. 2007). Tästä huolimatta potilaskeskeisyyden ja potilaan osallistumisen mahdollisuuksien lisääminen ovat nykyisen terveyspolitiikan keskeisiä päämääriä (Toiviainen 2007).

Laadulliset tutkimusmenetelmät tarjoavat välineitä potilaskeskeisyyden ja potilaan osallistumisen tutkimiseen. Aiemmassa, lääkärien ja potilaiden kohtaamista ja vuorovaikutusta käsittelevässä tutkimuksessa on keskitytty suurelta osin ennen kaikkea lääkärien toiminnan tutkimiseen (Drew 2001). Huomiota on kiinnitetty lääkärin suureen kontrollivaltaan suhteessa potilaan toimintaan vastaanotolla (Mishler 1984; Beckman \& Frankel 1984), jolloin potilaiden oma toiminta vastaanotolla ja heidän mahdollisuutensa ohjata vuorovaikutuksen suuntaa on jäänyt vähemmälle huomiolle (ks. kuitenkin Ruusuvuori 2000; Raevaara 2000). Myös lääkärin lääketieteellisen tietämyksensä nojalla saavuttama tiedollinen valta eli auktoriteetti on saanut paljon huomiota tässä keskustelussa, ja usein on nähty lääkärin auktoriteetin entisestään rajaavan potilaan osallistumismahdollisuuksia vastaanotolla (Fisher 1991; Davis 1988).

Tässä artikkelissa tarkastelemme keskustelunanalyyttisesti (Schegloff 2007; Heritage 1984) näitä molempia vallan osa-alueita (ks. Lukes 1978). Keskitymme vastaanoton vaiheeseen, jossa potilaalla on ehkä eniten mahdollisuuksia vaikuttaa vastaanoton kulkuun eli käynnin syyn kertomiseen (vrt. Heritage $\&$ Robinson 2006; Halkowski 2006). Tarkastelemme, miten potilaan tiedolliset oikeudet nousevat esiin tässä vaiheessa vastaanottoa ja millaisia seurauksia erilaisilla potilaan tavoilla kertoa käynnin syy on vastaanoton jatkolle: osallistujien tiedollisten asemien rakentumiselle ja toiminnalle vastaanotolla. (Collins ym. 2007; Peräkylä \& Ruusuvuori 2007; Peräkylä, Ruusuvuori \& Lindfors 2007; Ruusuvuori 2000.)

\section{POTILAAN VALTA VASTAANOTOLLA}

Lääkärin ja potilaan väliseen vuorovaikutukseen kiinnittyvän vallan voi jakaa kontrolliksi ja auktoriteetiksi (ks. Lukes 1978). Kontrollilla viitataan yhden osapuolen valtaan vaikuttaa toisen toimintaan. Vuorovaikutuksen tasolla esimerkiksi potilaan kysymys lääkärille velvoittaa lääkäriä vastaamaan siihen. Auktoriteetti taas tarkoittaa tiedollista valtaa, jossa yhden osapuolen näkemys asioiden tilasta näyttäytyy legitiimimpänä kuin toisen. Esimerkiksi lääketieteellisen tiedon katsotaan yleensä olevan lääkärin hallussa ja vuorovaikutuksessa potilas useimmiten mukautuu tähän tilanteeseen (Gill 1998; Peräkylä 1998; Raevaara 2000). Käytännössä nämä vallan ulottuvuudet ovat sisäkkäisiä, tiedollinen auktoriteetti voi tuottaa kontrollivaltaa. 
Käynnin syyn selvittämisen vaihetta vastaanoton alussa voi pitää merkittävänä vaiheena potilaan osallistumisen kannalta (Ruusuvuori 2005; Stivers $2002 b$ ). Se on paikka, jossa potilas tuo oman tietonsa terveysongelmastaan keskusteluun, ja tämän keskustelun pohjalta lääkäri selvittää terveysongelman luonnetta, päätyy todennäköiseen diagnoosiin ja suosittelee sopivaa hoitoa (Pendleton 1983; Keinänen-Kiukaanniemi ja Mäkelä 1991, 90; Ong, de Haes, Hoos \& Lammes 1995). Vuorovaikutuksellisen vallan näkökulmasta käynnin syyn kertomisen vaiheessa potilaalla on myös tilaisuus hallita keskustelun etenemistä: puhua itse pidempään vaikkapa kertomalla tarina oireidensa kehityksestä ennen kuin lääkäri ryhtyy haastattelemaan potilasta ja näin ottaa kontrollin itselleen (Ruusuvuori 2000; ks. myös Heritage \& Robinson 2006). Tässä tekstissä tarkastelemme, miten potilaat käyttävät tämän heille tarjoutuvan tilan. Erityisen mielenkiintomme kohteena ovat tilanteet, joissa potilaat käynnin syytä kertoessaan tuovat esiin oman näkemyksensä vaivansa laadusta sen sijaan, että kuvaisivat ainoastaan kokemiaan oireita - siis tilanteet, joissa potilas esittää diagnostisen arvelun ja astuu näin lääkärin auktoriteetin alueelle.

Potilaan diagnostisella arvelulla viittaamme käynnin syyn kuvauksiin, joissa potilas tuo esille jonkin tietyn diagnoosin (esimerkiksi poskiontelontulehdus) tai kertoo oireista, jotka selkeästi viittaavat tai ovat ominaisia jollekin tietylle diagnoosille (esimerkiksi korvatulehdus) (Stivers 2007, 28-36). On osoitettu, että tavallisesti potilaat pitävät diagnostista, lääketieteellistä päättelyä lääkärille kuuluvana toimintana: potilaat esittävät diagnoosiehdotuksia harvoin ja silloinkin ne ovat usein epävarmoja, arvelunkaltaisia puheenvuoroja (Stivers 2007, 28 \& 2002b; Heritage \& Robinson 2006; Ruusuvuori 2000, 164-166; Gill 1998.) Tämä viittaa siihen, että potilaan diagnoosiehdotus rikkoo lääkärin ja potilaan välistä tiedollista asymmetriaa potilaan astuessa lääketieteellisen tiedon ja päättelyn alueelle (Stivers 2002b; Raevaara 2000; Gill 1998). Potilaan diagnoosiehdotuksella voi kuitenkin olla erityisiä vuorovaikutuksellisia tehtäviä. Potilaat tekevät diagnoosiehdotuksia esimerkiksi tilanteissa, joissa heidän vastaanotolle saapumisensa oikeutus asettuu jollain tavoin kyseenalaiseksi. Tällöin diagnoosiehdotus voi toimia potilaan käyntipäätöstä legitimoivana: hän on arvellut ongelmansa olevan vakavampaa laatua kuin se, joksi se tutkimuksessa osoittautuu. (Raevaara 2000.)

Stivers (2007; 2002b) on tutkinut käynnin syyn kertomisen vaihetta lastenlääkärin vastaanotolla ja osoittanut, että diagnoosiehdotuksen sisältävä käynnin syyn kuvaus luo vastaanotolle tietynlaisen odotuksen. Esittäessään "vain oireet" käynnin syynä lapsen vanhempi asemoituu odottamaan lääkäriltä ensisijaisesti arviota lapsen terveydentilasta. Sen sijaan ehdottaessaan diagnoosia vanhempi näyttää hakevan lääkäriltä vahvistusta kyseiselle diagnoosille sekä sitä vastaavaa hoitoa, kuten antibiootteja. Tutkimus kuitenkin jättää kysymyksen aikuispotilasvastaanottojen vastaavista keskustelun käytänteistä avoimeksi ja kysyy, voiko potilaan diagnostisen arvion luoma odotus antibioottihoidosta olla myös niin kutsutusti tahaton teko. Kyselytutkimukset ovat osoittaneet, että potilaiden vanhemmat eivät raportoi odottavansa tiettyjä hoitoja eivätkä vanhempien todelliset odotukset ja lääkäreiden olettamat vanhempien odotukset välttämättä ole yhteneväiset (Stivers 2002b; Mangione-Smith, McGlynn, Elliott, Krogstad \& Brook 1999). Tässä artikkelissa osallistumme keskusteluun diagnostisten arvelujen tehtävästä vastaanotolla analysoimalla sekä lapsi- että aikuispotilaiden vastaanottoja. 


\section{TUTKIMUKSEN AINEISTO JA METODI}

Tutkimuksen aineistona on 86 potilaan videoidut vastaanotot. Näistä 38 on aikuispotilaiden ja 39 lapsipotilaiden vastaanottoja, ja neljällä vastaanotolla on useampi potilas, esimerkiksi sisarukset vanhempansa kanssa (yhteensä 9 potilasta). Rajasimme aineiston vain ylähengitysteiden ja korvien oireiden takia vastaanotolle tulleisiin, mikä helpottaa eri vastaanottojen toimintajaksojen vertailua. Kaikki tutkimukseen osallistuneet 11 lääkäriä yhdeksästä eri terveyskeskuksesta eri puolilta Suomea sekä $98^{1}$ potilasta ovat antaneet kirjallisen suostumuksensa vastaanottojensa videointiin. Videoinnit toteutettiin vuosien 2005-2006 aikana. Videoaineisto on purettu tekstiksi eli litteroitu keskustelunanalyysin konventioin (Jefferson 1984) (ks. liite).

Keskustelunanalyysissa tutkitaan sosiaalisen toiminnan ja järjestyksen perustavinta muotoa eli sosiaalista, kasvokkaista vuorovaikutusta sekä sitä, millaisten vuorovaikutuksen "sääntöjen" ja rakenteiden avulla sosiaalisissa tilanteissa on mahdollista toimia (Schegloff 2007; Heritage 1984; Peräkylä 1997). Tarkastelun kohteena on se, millaisia toimintoja tarkastellun vuorovaikutustilanteen osallistujat itse pitävät odotuksenmukaisina ja tilanteeseen sopivina. Tässä esitetty analyysi kohdistuu erityisesti kahteen seikkaan: puheenvuorojen jäsentymiseen toimintajaksoiksi eli sekvensseiksi (Schegloff 2007; Sacks, Schegloff \& Jefferson 1974; Schegloff \& Sacks 1973) sekä osallistujien episteemisiin eli tiedollisiin asemiin näissä sekvensseissä (Heritage \& Raymond 2005). Tarkasteltava sekvenssi on käynnin syyn kuvaus ja sen vastaanottaminen.

Seuraavassa analysoimme ensin aineistossamme useimmin esiintynyttä ${ }^{2}$ vastaanottovuorovaikutuksen tapaa eli vastaanottoa, jolla potilas kertoo vain oireet käynnin syynä (Ruusuvuori 2000; Stivers 2002b) esittämättä diagnostista arvelua. Tarkastelemme, miten vuorovaikutus jäsentyy ja miten tiedolliset asemat muodostetaan tällaisella vastaanotolla. Tämä toimii vertailukohtana vastaanotoille, joilla potilas esittää diagnostisen arvelun käyntinsä syyn kuvauksessa. Kuvaamme, millaisten keskustelun käytänteiden avulla potilaat diagnostisia arveluita tuottavat sekä miten diagnostisen arvelun tuottamisen tapa on yhteydessä sen vastaanottamisen tapoihin. Lopuksi pohdimme tulosten suhdetta aikaisempaan keskusteluun potilaan tiedollisista oikeuksista ja osallistumisesta lääkärin vastaanotolla sekä asetamme kysymyksiä jatkotutkimukselle.

\section{VAIN OIREET KÄYNNIN SYYN KUVAUKSENA}

Analysoimme ensin vastaanottoa, jossa lääkäriä kohdellaan lääketieteellisen tiedon haltijana. Näissä tapauksissa potilas kuvaa käyntinsä syytä luettelemalla kokemiaan oireita ja antaa näin lääkärille materiaalia diagnoosia ja hoito-ohjeita varten. Esimerkki on aikuispotilaan vastaanotolta. Litterointimerkkien selitykset näkyvät liitteessä. 


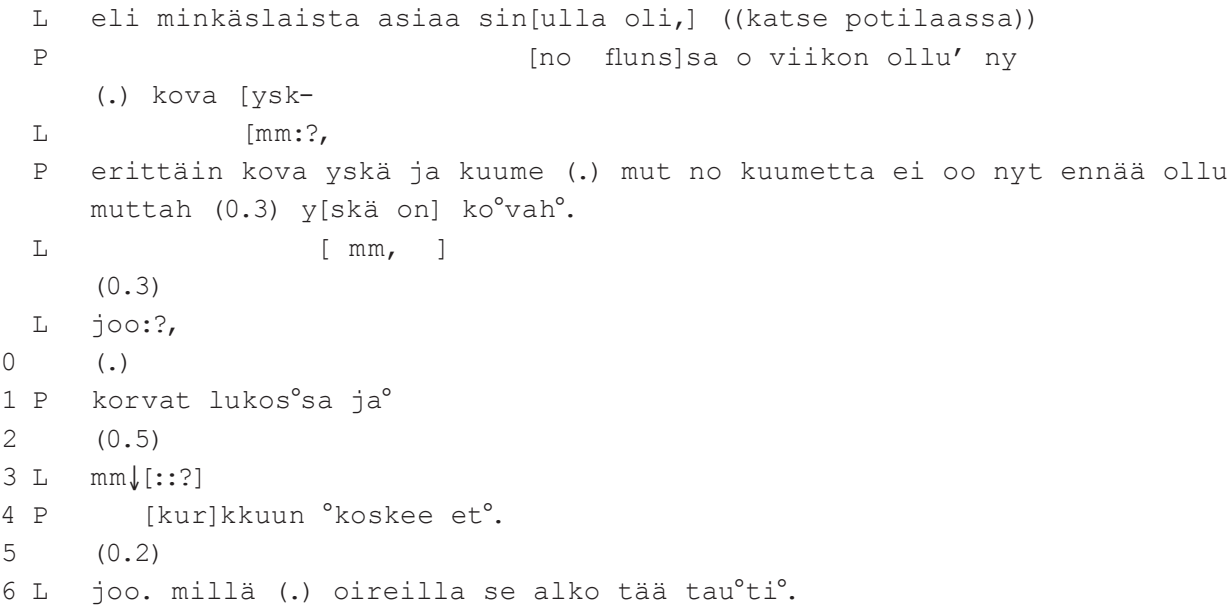

Potilas rakentaa käyntinsä syyn kuvauksen oireiden luetteloksi: häntä on vaivannut flunssa, jonka oireina hän mainitsee aluksi yskän ja kuumeen (rivit 26) ja hetken kuluttua lääkärin jatkamiskehotuksen "joo?" jälkeen myös lukossa olevat korvat (r. 11) ja kurkkukivun (r. 14). Potilaan käynnin syyn kuvauksen toinen vaihe on valmis rivin 14 lopussa, jossa vaimeneva ääni ja laskeva vuoronloppuinen intonaatio osoittavat vuoron päättymistä ja lääkärin mahdollisuutta ottaa seuraava vuoro. Pienen tauon ( $r$. 15) jälkeen lääkäri alkaakin selvittää potilaan ongelman yksityiskohtia ( $r .16)$.

Lääkäri ottaa potilaan oirekuvauksen vastaan minimipalauttein ja jatkamiskehotuksin $(r .4,7,9,13)$. Kun potilas ei enää kuvaa oireita vaan vaikenemalla osoittaa kuvauksensa päättyneen, lääkäri siirtyy selvittämään oireiden alkamisajankohtaa. Näin lääkäri tekee tiettäväksi, että potilaan kuvaus on riittävä, jotta esitettyyn ongelmaan voidaan lähteä etsimään ratkaisua (Ruusuvuori 2000, 150; Robinson \& Stivers 2001). Osallistujat toimivat institutionaalisten rooliensa mukaisesti, eivätkä heidän episteemiset asemansa nouse erityisellä tavalla esiin keskustelussa.

Esimerkissä potilas ja lääkäri orientoituvat lääkärin oikeuteen aloittaa uusi vaihe eli fyysinen tutkimus vastaanotolla: heidän toiminnastaan on pääteltävissä, että potilas on saanut kuvailla oirettaan riittävästi ja että lääkäri voi siirtyä tutkimaan potilaan ongelmaa. Potilas osoittaa laskevalla intonaatiollaan sekä pysyttelemällä hiljaa kohdissa, joissa hänellä olisi ollut mahdollisuus ottaa vuoro, että lääkäri on vapaa ottamaan keskustelun ohjat käsiinsä. Lääkäri puolestaan ottaa tarjotun mahdollisuuden vastaan puheenvuorollaan "joo" (r. 16), mikä ehdottaa aiemman puhejakson päättämistä, sekä uuden toiminnon aloittavalla puheenvuoronsa jatkolla (nonverbaaleista käytänteistä uuden jakson aloittamisessa ks. Robinson \& Stivers 2001).

Lääkärin ja potilaan tiedolliset asemat eivät nouse vain oireisiin liittyvissä käynnin syyn kuvauksissa käsittelyyn millään erityisellä tavalla. Muotoilemalla kuvauksensa kokemiensa oireiden luetteloksi potilaat asemoituvat subjektiivisesta kokemuksesta ja/tai havainnosta kertovan maallikon asemaan, mikä ei tee odotuksenmukaiseksi potilaan kokemuksen relevanssin punnitsemista. Potilaan kokemuksen arvioiminen voisi olla jopa arkaluontoista (Peräkylä \& Sil- 
verman 1991). Lääkärit taas vastaanottavat vain oireista kertovia käynnin syyn kuvauksia minimipalautteilla ja siirtyvät käynnin syyn kuvauksen jälkeen vastaanoton vaiheesta toiseen (vrt. Collins tulossa). Vain oireisiin liittyvä käynnin syyn kuvaus johtaa tyypillisen lääkäri-potilas-vuorovaikutuksen "perusproseduurin" toteutumiseen vastaanotolla (Heritage \& Maynard 2006, 14; Robinson 2003). Kun sekä lääkäri että potilas kohtelevat potilaan oirekuvausta riittävänä, lääkärillä on osallistujien yhteisesti rakentaman, tilanteisesti tuotetun ymmärryksen pohjalta valta esittää, milloin seuraavaan toimintoon siirtymisen kannalta riittävä ja relevantti tieto on tullut esille (Ruusuvuori 2000).

Osallistujien tiedollisten asemien määrittely tulee eri tavoin esiin vastaanotoilla, joilla potilas tai potilaan vanhempi ehdottaa tai arvelee diagnoosia osana käyntinsä syyn kuvausta. Tämä näkyy myös vastaanoton alun sekventiaalisessa rakenteessa: tapa jolla potilas diagnostisen arvelunsa tuottaa, näyttäisi ohjaavan lääkärin tapaa käsitellä sitä.

\section{POTILAAN DIAGNOSTISEN ARVELUN HUOMIOON OTTAMINEN}

Kun potilaat esittävät käyntinsä syyn siten, että se sisältää diagnostisen arvelun, osallistujien tiedolliset asemat ja oikeudet nousevat esiin (Stivers 2007; 2002b). Aineistossamme lääkärit ottavat poikkeuksetta potilaan diagnostisen arvion käsiteltäväksi joko välittömästi potilaan oirekuvauksen jälkeisessä puheenvuorossaan tai palaamalla siihen vastaanoton myöhemmissä vaiheissa. Tämä vaikuttaa myös vastaanoton kulkuun. Seuraavassa kuvaamme, miten potilaiden diagnostisen arvelun tuottamisen tapa ohjaa lääkärin toimintaa hänen seuraavassa puheenvuorossaan tai myöhemmin vastaanotolla. Tarkastelemme ensin vastaanottoja, joissa diagnostista arvelua käsitellään välittömästi.

Aineistossamme lääkäri nostaa potilaan diagnostisen arvion käsittelyyn välittömästi seuraavassa vuorossa silloin, kun potilas tai potilaan vanhempi esittää sen kuvauksensa keskeisenä elementtinä. Eli silloin kun potilas esittää sen oirekuvauksen alussa oirekategoriana, jota sitten perustellaan, tai oirekuvauksessa esitettyjen yksittäisten oireiden lopputulemana. Tällöin myös osallistujien episteemiset asemat tehdään näkyväksi keskustelussa. Esimerkissä 2 vastaanoton potilas on aikuinen.

\section{Esimerkki 2 (Vastaanotto 10)}

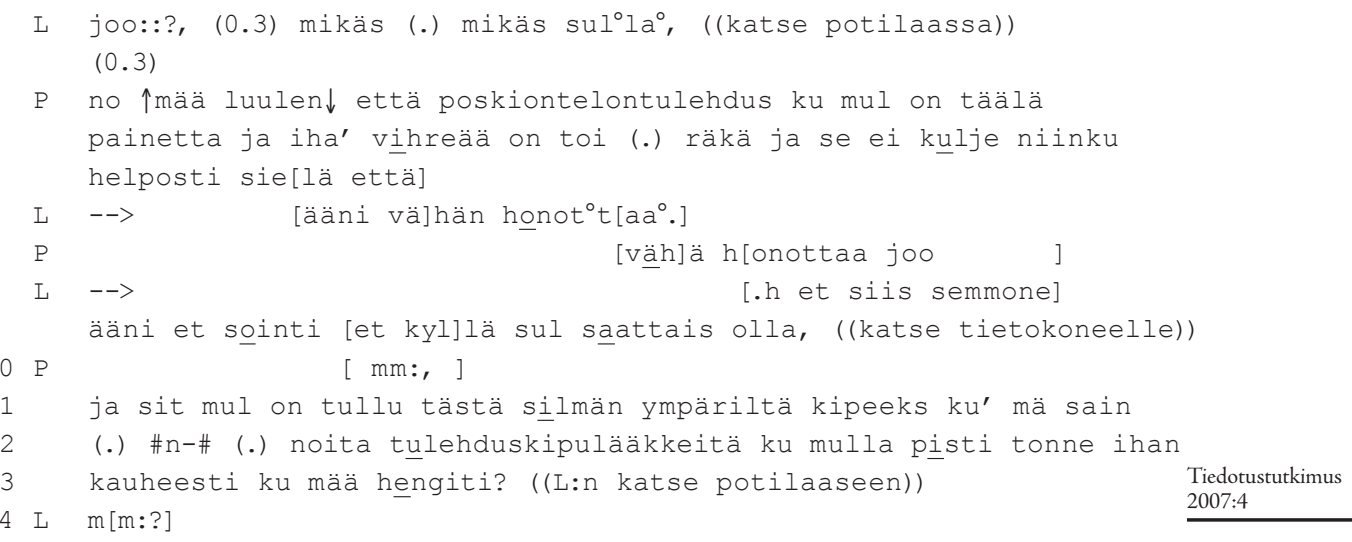


Potilaan käynnin syyn kuvauksen ensimmäinen osa"no mää luulen että poskiontelontulehdus" toimii tarinan otsikkona ja ehdottaa diagnoosia suoraan ( $r$. 3). Tämän jälkeen potilas kuvaa ongelmaansa liittyviä oireita tavalla, joka tarjoaa selityksen arvellulle diagnoosille: "ku mul on täällä painetta..." (r. 3-4). Käyttämällä partikkelia "kun" potilas ikään kuin tuottaa perustellun väitteen ehdotetusta diagnoosista. Välittömästi seuraavassa vuorossaan lääkäri tarttuu potilaan tarjoamaan diagnostiseen arveluun ottamalla kantaa sen oikeellisuuteen. Rivillä 6 lääkäri aloittaa oman vuoronsa puhuen potilaan vuoron päälle, ja tuo esille oman havaintonsa potilaan diagnoosiehdotuksen kontekstissa. Lääkärin vuoron ensimmäinen osa "ääni vähän honottaa" kuvaa lääkärin tekemän havainnon (r. 6) ja vuoron toinen osa "et siis semmone ääni et sointi et kyllä sul saattais olla" (r. 8-9) vahvistaa potilaan diagnostisen arvelun mahdollisesti oikeaksi, mutta tekee sen nojautumalla lääkärin itsensä tekemään havaintoon.

Lääkäri ei siis siirry suoraan anamneesiin eli esitietojen selvittämiseen ( $r$. 19) käynnin syyn kuvauksen jälkeen vaan laajentaa käynnin syyn kuvauksen ja vastaanottamisen sekvenssiä (r. 6-10) (Schegloff 2007, 106-109) tavalla, joka nostaa osallistujien episteemiset asemat erityisellä tavalla käsittelyyn keskustelussa. Kun potilas esittää diagnostisen arvelun käyntinsä syyn kuvauksen keskeisenä elementtinä ja tarjoaa sen lääkärille vastattavaksi, potilas asettuu (ehdollista) lääketieteellistä tietoa omaavan osapuolen asemaan. Toisin kuin vain oireiden kuvailuun liittyvillä vastaanotoilla, lääkäri ei siirry suoraan seuraavaan vastaanoton vaiheeseen, vaan kommentoi potilaan esittämää diagnostista arvelua. Hän tekee tämän kuitenkin viittaamalla ensisijaisesti omiin, ei potilaan tekemiin, havaintoihinsa ja säilyttää näin lääkärin auktoriteetin lääketieteellisten päätelmien tekijänä. Toinen esimerkki on vastaanotolta, jonne isä on tuonut noin puolitoistavuotiaan vauvan.

\section{Esimerkki 3 (Vastaanotto 17)}

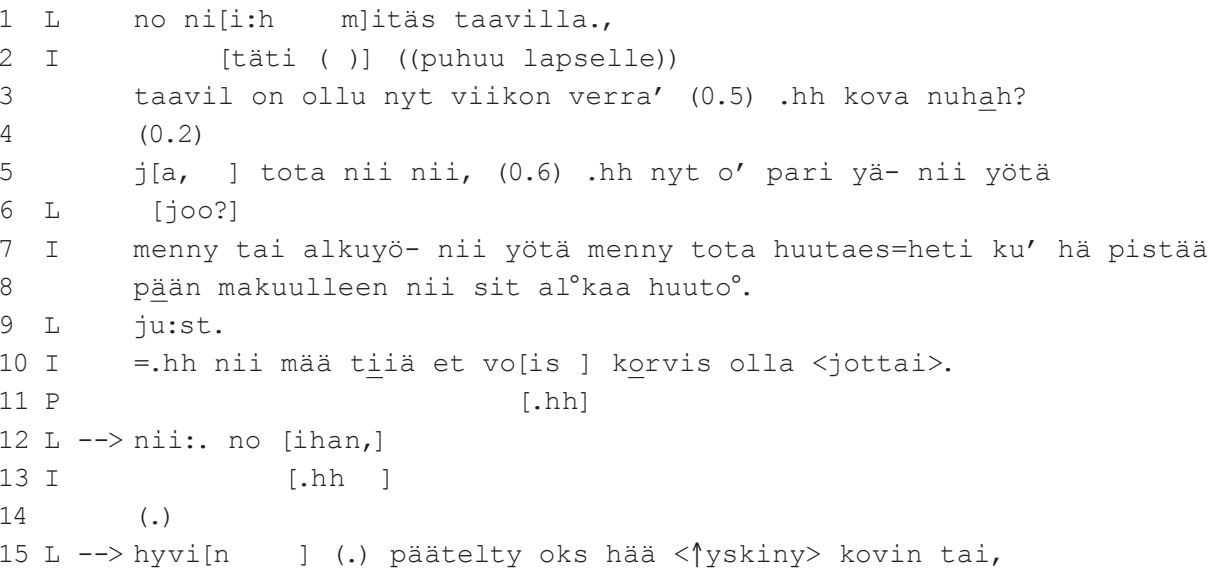


Esimerkissä isän kertoma tarina lapsen ongelmasta tuo diagnostisen arvelun taustalla olevan päättelyn esille "eri järjestyksessä" kuin edellisessä esimerkissä. Isän puheenvuoron ensimmäinen osa "taavil on ollu nyt viikon verra kova nuha" (r. 3) on tarinarakenteelle tyypillinen otsikko, jota ei kuitenkaan ole tuotettu riittävänä tai valmiina käynnin syyn kuvauksena (ks. Jefferson 1985). Lääkäri orientoituu isän puheenvuoroon vastaavalla tavalla, sillä "joo" (r. 6) kehottaa isää jatkamaan käynnin syyn kuvausta. Seuraavassa vuoronrakenneyksikössään "heti ku hä pistää pään makuulleen nii sit alkaa huuto" (r. 7-8) isä kuvaa päättelyään diagnostisen arvelun taustalla. Lääkäri ottaa tämän vastaan ikään kuin valmiina oirekuvauksena lausumallaan "just" (r. 9). Välittömästi tämän jälkeen isä ottaa kuitenkin vuoron takaisin itselleen. Hän esittää diagnostisen arvelun "nii mää tiiä et vois korvis olla jottai" (r.10). Esittämällä omaa epätietouttaan lääkärin asiantuntemuksen alueelle kuuluvasta seikasta isä tarjoaa sen lääkärille vastattavaksi (ks. Pomerantz 1980). Partikkelilla "että" ja sijoittamalla diagnostisen arvelun vuoronsa viimeiseksi osaksi isä esittää sen päätelmänä edellä kertomastaan (nuha ja huuto makuuasennossa viittaa korvatulehdukseen). Näin lopussa esitetty diagnostinen arvio asettuu kuvauksen keskeiseksi elementiksi.

Lääkäri huomioi isän diagnostisen arvelun puheenvuorossaan ( $\left.r_{+} 12\right)$ tavalla, joka nostaa osallistujien tiedolliset asemat keskusteluun. Lääkäri suhtautuu isän diagnostiseen arveluun yhtenä mahdollisuutena: lääkärin "nii" (r. 12) ei ole selkeästi saman- tai erimielinen vastaus isän diagnostiseen arveluun (Sorjonen 2001). Sen sijaan lääkäri ottaa tiedollisen auktoriteettiaseman itselleen arvioidessaan isän havaintoja ja päättelyä puheenvuorossaan "nii no ihan hyvin päätelty" (r. 11-15). Lääkäri osoittaa oikeuttaan arvioida isän tekemää päättelyä. Lääkärin vuorossa näkyy siis myös tiedollisten asemien välinen jännite. Lääkärin vuoron alun partikkelit "nii" ja "no" implikoivat mahdollista erilinjaisuutta, jopa mahdollista erimielisyyttä lääkärin ja isän välillä (Sorjonen 2001). Osallistujat myös käsittelevät isän käynnin syyn kuvausta siirtyen seuraavaan toimintoon suoraan diagnoosiehdotuksen käsittelyn jälkeen. Käynnin syyn kuvaukselle ei odoteta mahdollista jatkoa (kuten vain oireiden kuvailun vastaanotoilla).

Viimeisessä esimerkissä lääkäri ei kommentoi potilaan käynnin syyn kuvaukseen sisältyvää diagnoosiehdotusta sanallisesti, mutta hänen sitä seuraava toimintansa kohtelee potilaan ehdotusta tutkimisen arvoisena asiana.

\section{Esimerkki 4 (Vastaanotto 14)}

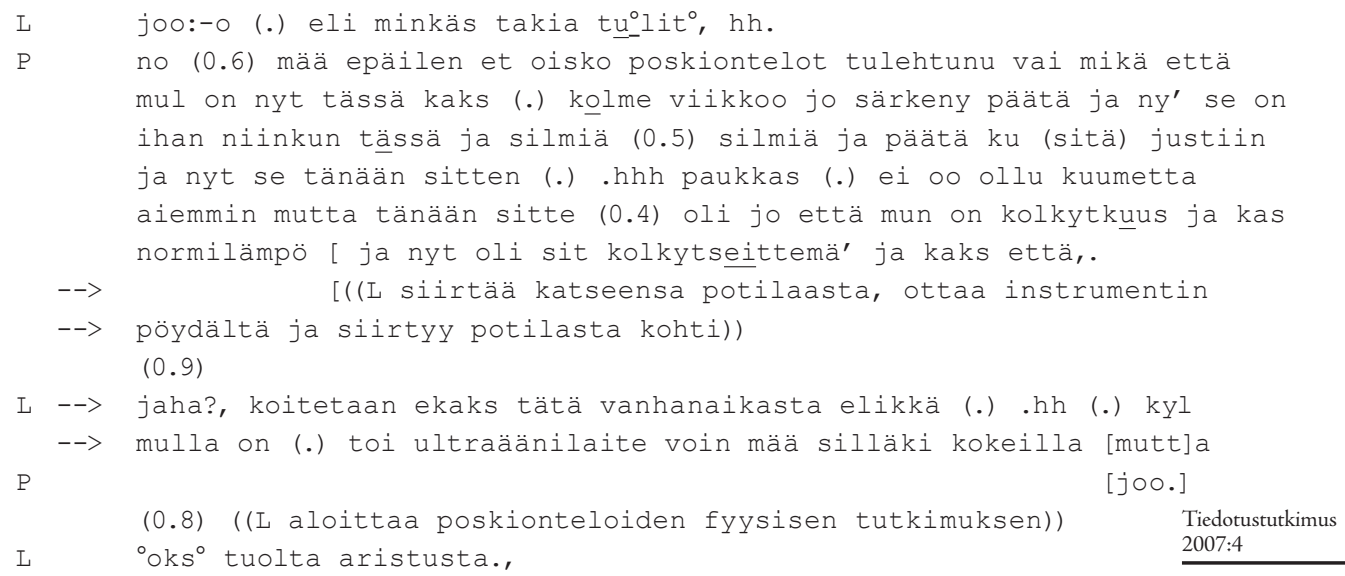


Kuten esimerkissä 2, myös tässä potilas tuottaa diagnostisen arvelunsa "oisko poskiontelot tulehtunu" heti vuoronsa alussa (r. 2) ja kertoo tämän jälkeen oireistaan perusteluna epäilylleen. Eli potilas tuottaa diagnostisen arvelunsa kuvauksensa keskeisenä ja lääkärille vastattavaksi tarjoutuvana elementtinä. Lääkäri aloittaa uuteen vaiheeseen orientoitumisen välittömästi diagnostisen arvelun sisältävän käynnin syyn kuvauksen jälkeen, aloittamalla siirtymisen uuteen vaiheeseen katseen suunnan ja asennon muutoksella. Rivillä 7 potilaan yhä kertoessa kuumeestaan, lääkäri siirtää katseensa pois potilaasta ja kääntyy ottamaan poskionteloiden tutkimiseen tarvittavaa instrumenttia pöydältä (vrt. Ruusuvuori 2001). Hän myös kertoo potilaalle fyysiseen tutkimukseen siirtymisestä sitoessaan puheenvuoronsa potilaan odotuksenmukaiseksi tekemään kontekstiin "koetetaan ensiksi tätä vanhanaikaista” (r+9), mikä viittaa siihen, että lääkäri tutkii poskiontelontulehduksen mahdollisuutta instrumentilla koputtelemalla eikä ultraäänilaitteella. Näin lääkäri siirtyy uuteen toimintoon vastaanotolla potilaan diagnoosiehdotuksen ohjaamana (Robinson \& Stivers 2001).

Tässä esimerkissä lääkäri antaa potilaan diagnostiselle arvelulle jälleen hieman erilaisen episteemisen aseman verrattuna aikaisempiin esimerkkeihin. Lääkäri ei ehdollista tai arvioi potilaan tietoa, havaintoja, kokemusta tai päättelyä verbaalisti, vaan sen sijaan aloittaa uuden toiminnon suhteessa potilaan esittämään diagnostiseen arvioon ja osoittaa siten potilaan diagnoosiehdotuksen merkityksellisyyden seuraavassa toiminnassaan. Lääkärin toiminta näyttäisi tähtäävän suoraan potilaan diagnoosiehdotuksen vahvistamiseen tai epäämiseen. Toiminnallaan lääkäri kuitenkin jälleen säilyttää lääketieteellisen auktoriteettinsa, hän ottaa potilaan ehdotuksen huomioon, mutta ei esitä saman- tai erimielisyyttä sen kanssa, vaan ryhtyy selvittämään tilannetta.

Aineisto osoittaa, että kun potilas tai potilaan vanhempi tuottaa diagnostisen arvion käynnin syyn kuvauksensa keskeisenä elementtinä, ottaa lääkäri sen tavalla tai toisella huomioon välittömästi seuraavassa toiminnassaan. Tällöin diagnostiset arvelut voidaan tuottaa joko käynnin syyn kuvauksen ensimmäisenä elementtinä, jonkinlaisena "otsikkona", jolle tuotetaan perusteluja (esimerkit 2 ja 4), tai viimeisenä elementtinä, selityksenä kerrotuille oireille (esimerkki 3). Molemmissa tapauksissa käynnin syyn kuvaus on rakennettu siten, että diagnostinen arvelu tarjoutuu lääkärille vastattavaksi. Diagnostisella arvelullaan potilas osoittaa, että hänellä on lääketieteellistä tietoa ja että hän voi tuoda esille lääketieteellistä päättelyä. Vaikkakin tämä tieto esitetään usein epävarmuutta esille tuoden:"no mää luulen että poskiontelontulehdus" (esimerkki 2).

Lääkäri voi orientoitua eri tavoin potilaan tiedolliseen asemaan. Hän voi 1) arvioida potilaan diagnostisen arvelun mahdollista oikeaan osumista nojautumalla omiin havaintoihinsa (esimerkki 2), 2) arvioida potilaan päättelyn relevanssia orientoituen myös mahdolliseen erimielisyyteen (esimerkki 3) tai 3) hyväksyä potilaan diagnostisen arvelun ja kohdella sitä relevanttina siten, että seuraava toiminto tähtää suoraan potilaan diagnostisen arvelun vahvistamiseen tai hylkäämiseen (esimerkki 4). Diagnostisen arvelun huomioivassa vuorossaan lääkäri siis nostaa sekä potilaan että oman tiedollisen asemansa vuorovaikutuksessa näkyväksi ja käsiteltäväksi asiaksi. Kaikissa tapauksissa lääkäri myös palauttaa oman asemansa lääketieteellisen tiedon haltijana.

Aina lääkärit eivät kuitenkaan nosta potilaan diagnostista arvelua keskustelussa käsiteltäväksi välittömästi seuraavassa vuorossaan, vaan voivat siirtyä suoraan haastattelemaan tai tutkimaan potilasta (kuten vain oireiden kuvailun jäl- 
keen). Huomionarvoista kuitenkin on, että lähes kaikilla ${ }^{3}$ vastaanotoilla lääkärit palaavat potilaan diagnostiseen arveluun viittaamalla siihen vastaanoton myöhemmissä vaiheissa, tavallisesti fyysisen tutkimuksen ja/tai hoitoneuvottelun aikana (vrt. Heritage \& Stivers 1999). Näin tapahtuu seuraavissa esimerkeissä, joissa diagnostisen arvelun sisältävä käynnin syyn kuvaus on muotoiltu eri tavoin kuin edellä nähdyissä esimerkeissä 2-4.

\section{POTILAAN DIAGNOSTISEN ARVELUN OHITTAMINEN}

Kun diagnostinen arvelu esitetään sivuhuomautuksena, esimerkiksi tuomaan lisätietoa oireista, lääkäri voi jättää sen huomiotta seuraavassa puheenvuorossaan. Tällöin käynnin syyn kuvaukseen sisältyvä diagnostinen arvelu on upotettu kuvaukseen siten, että se ei tarjoudu lääkärin vastattavaksi. Myös näissä tapauksissa lääkärit kuitenkin kommentoivat diagnostista arvelua tavalla tai toisella myöhemmin vastaanotolla. Ensimmäinen esimerkki tästä on vastaanotolta, jossa potilaana on keski-ikäinen nainen.

\section{Esimerkki 5a (Vastaanotto 62)}

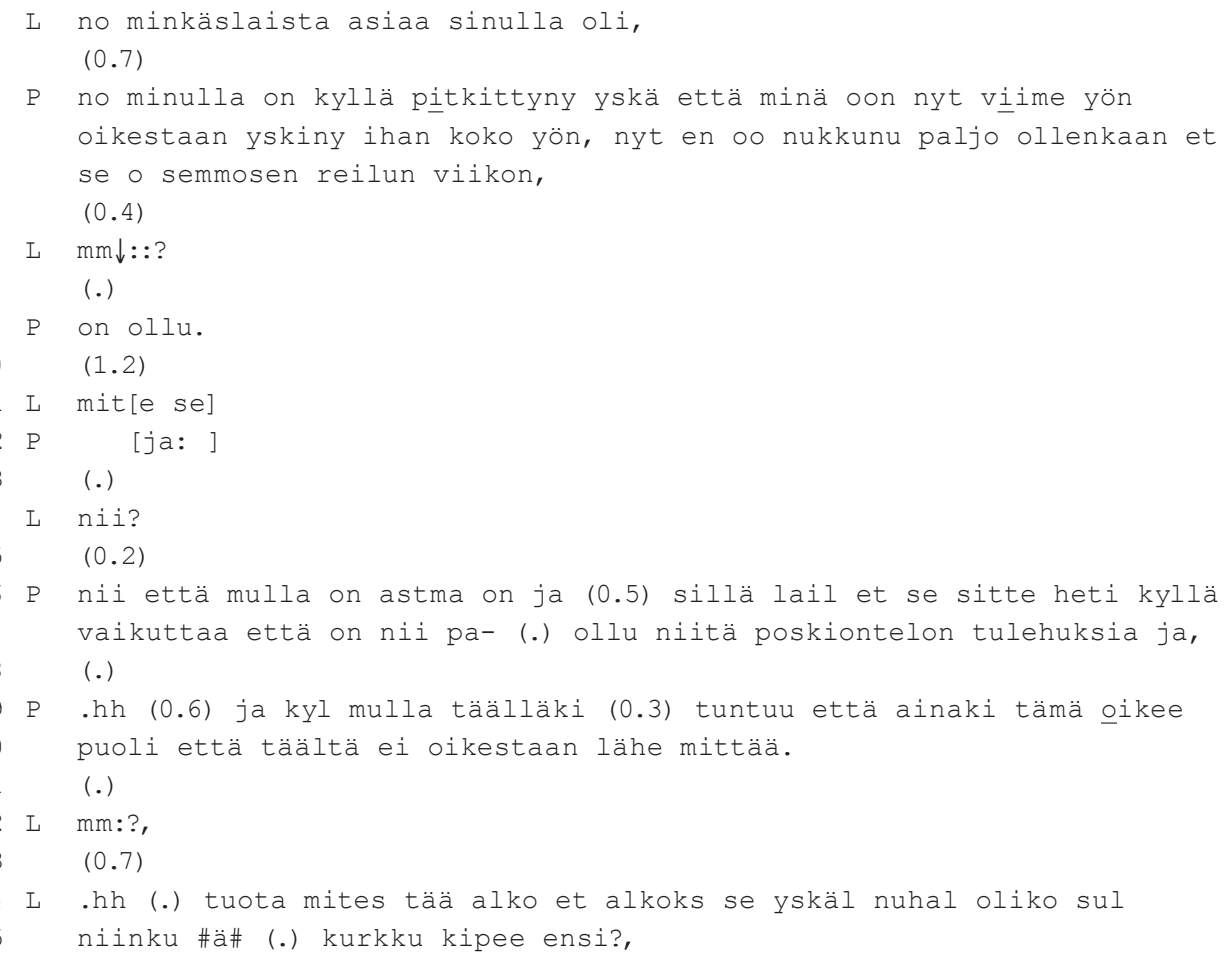

Yksi tapa tuottaa diagnostinen arvelu on kertoa oireista sitomalla ne kertomukseen aiemmasta sairaushistoriasta. Tällöin potilas voi viitata diagnoosiin tarjoamatta sitä lääkärille vastattavaksi puheenvuoronsa keskeisenä elementtinä. Tässä esimerkissä potilas aloittaa käynnin syyn kertomisen kuvaamalla ongelmaansa tavalla, jossa on sekä listarakenteen että tarinan piirteitä. Potilaan käynnin syyn ensimmäinen osa on syntaktisesti valmis rivillä 9, mutta 
kuultavissa valmiina jo rivillä 4. Pitkän, 1.2 sekunnin tauon jälkeen lääkäri on aloittamassa potilaan haastattelua ( $r .11)$, mutta keskeyttää puheensa potilaan jatkaessa oirekuvaustaan ( $r$. 12). Lääkäri kehottaa potilasta jatkamaan (r. 14), minkä jälkeen potilas tuottaa diagnostisen arvelun osaksi käyntinsä syyn kuvausta ja liittää kokemuksensa aikaisempiin poskiontelontulehduksiin. Potilas kuitenkin jatkaa kuvaustaan (ja-sana rivin 17 lopussa vihjaa, että kuvaus jatkuu) ja päättää puheenvuoronsa rivien 19-20 oirekuvaukseen. Potilaan diagnostinen arvelu on upotettu tarinaan, jossa viimeiseksi lääkärin tartuttavissa olevaksi elementiksi jää koettujen oireiden kuvaus, ei diagnostinen arvio.

Lääkäri ottaa potilaan käynnin syyn kuvauksen ja siihen sisältyvän diagnostisen arvelun vastaan nousevalla intonaatiolla lausutulla " $m$ m"-lausumalla ( $r$. 22), jolla rekisteröi kuulemansa ja antaa vielä potilaalle mahdollisuuden ottaa vuoron itselleen. Potilas ei kuitenkaan jatka vuoroaan, joten lääkäri aloittaa seuraavan vaiheen vastaanotolla ryhtymällä haastattelemaan potilasta rivillä 24. Lääkärin "mites tää"-alkuinen kysymys vaikuttaisi rivillä 11 keskeytyneen kysymyksen alun toistolta. Kysymyksessä hän myös ottaa esiin potilaan jo alussa ilmoittaman oireen (yskä, r. 3), mutta ei viittaa millään tavalla potilaan diagnostiseen arveluun. Lääkäri aloittaa käynnin syyn kertomusta seuraavan vaiheen samalla tavoin kuin vastaanotoilla, joilla potilas kertoo "vain oireet" (ks. esim. 1). Silloin kun lääkärit ohittavat potilaan diagnostisen arvelun tällä tavoin, he kuitenkin järjestelmällisesti (ks. viite 3) palaavat potilaiden diagnostisiin arveluihin viittaamalla niihin vastaanoton myöhemmissä vaiheissa. Seuraava aineisto-ote on samalta vastaanotolta vaiheesta, jossa fyysinen tutkimus on päättymässä ja lääkäri aloittaa diagnoosin kertomisen.

\section{Esimerkki 5b (Vastaanotto 62)}

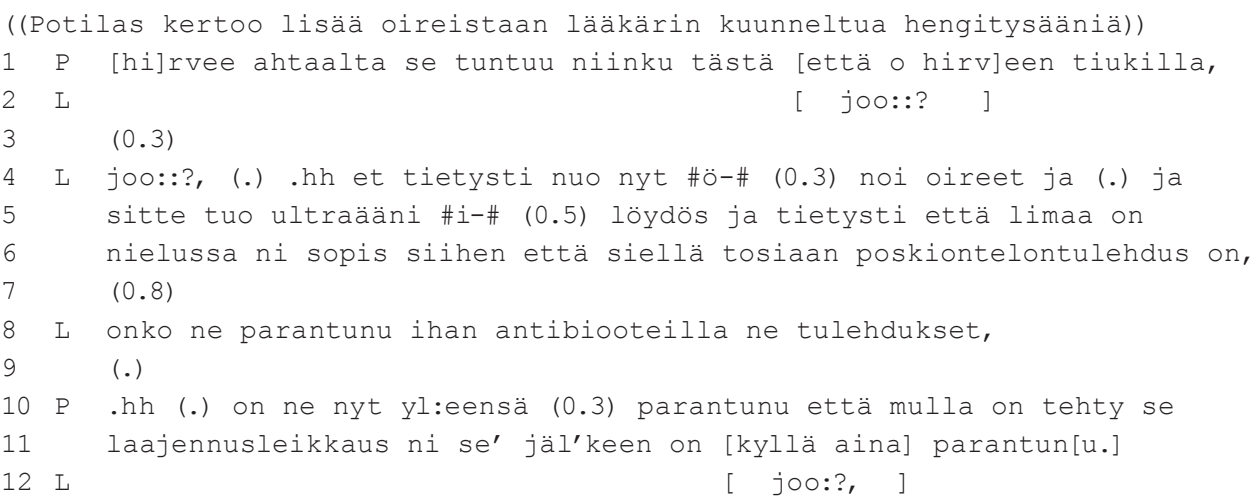

Tässä katkelmassa näkyy, miten diagnoosin kertominen ja hoitopäätöksen tekeminen vastaanotolla tapahtuvat potilaan käynnin syyn kuvauksen odotuksenmukaiseksi tekemässä kontekstissa: rivin 6"siellä tosiaan poskiontelontulehdus on" vahvistaa potilaan vastaanoton alussa esittämän epäilyn todeksi. Lääkäri kuitenkin rakentaa diagnoosille lääketieteellisen, "professionaalin" pohjan esittämällä kenen tietoon ja millaisiin perusteisiin diagnoosi perustuu ( $r$. 4-6). Tämän jälkeen lääkäri viittaa hoitoon, jota hän tulee potilaalle tarjoamaan kysymällä "onko ne parantunu ihan antibiooteilla ne tulehdukset" (r. 8). Mainitsemalla "ne tulehdukset" hän kontekstoi viittauksensa potilaan 
käynnin syyn kerronnan yhteydessä esittämään diagnostiseen arveluun ja kertomukseen sairaushistoriasta. Seuraava esimerkki on vastaanotolta, jossa potilaana on nuori nainen.

\section{Esimerkki 6a (Vastaanotto 60)}

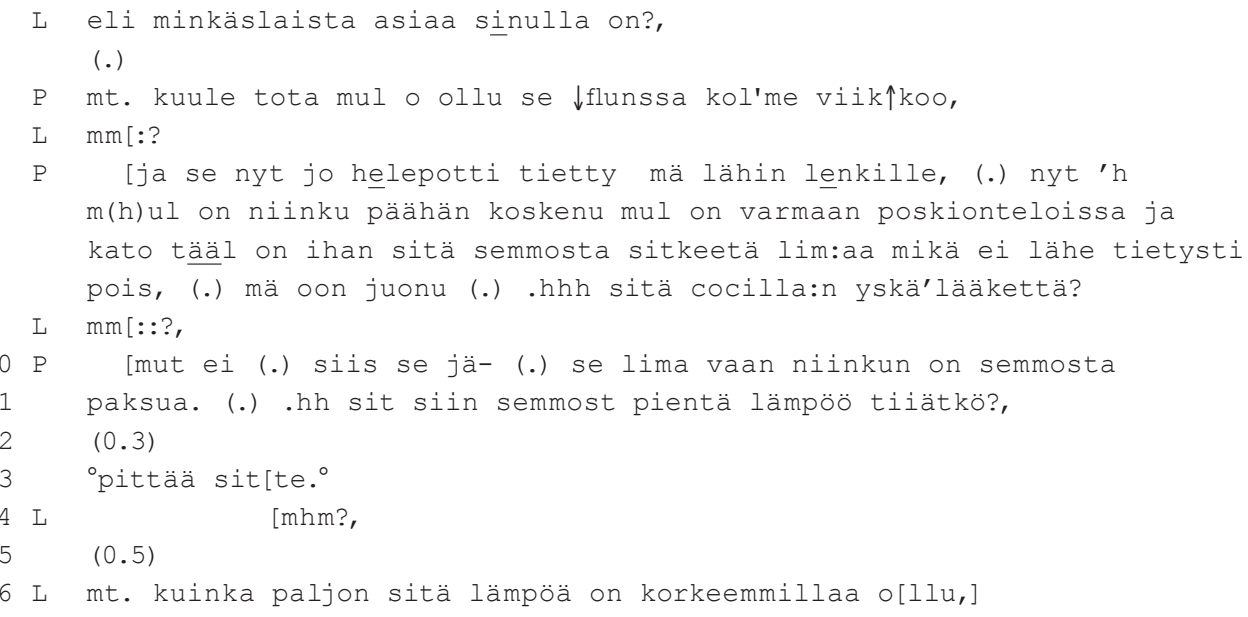

Aineisto-ote on esimerkki toisesta tyypillisestä tavasta tuottaa diagnostinen arvelu osana käynnin syyn kuvausta tuottamatta sitä puheenvuoron keskeisenä elementtinä. Edellisessä esimerkissä diagnostinen arvelu sidottiin osaksi aiempaa sairaushistoriaa, tässä esimerkissä potilas esittää diagnostisen arvelun osana kuvausta pidempään jatkuneista oireista. Potilaan käynnin syyn kuvaus alkaa otsikolla rivillä 3: "mul o ollu se flunssa kolme viikkoo" luo tulkintakehyksen potilaan tulevalle oirekuvaukselle ja esittää vaivan jatkumisen jo pitkään. Diagnostinen arvelu $(r, 6)$ tuotetaan taustalla olevana selityksenä kerrotuille oireille ja sairauden etenemisen kuvaukselle. Rakenteellisesti se on upotettu tarinaan taustaelementtinä, kun viimeiseksi, lääkärin tartuttavissa olevaksi elementiksi jäävät potilaan itsehoito yskänlääkkeellä ( $r+8)$ ja oireiden (lima ja lämpö r. 10-11) kuvaus.

Vaikka lääkäri ohittaa diagnostisen arvelun käynnin syyn kuvausta vastaanottavassa vuorossaan, hän palaa siihen vastaanoton myöhemmissä vaiheissa. Seuraava ote on fyysisen tutkimuksen vaiheesta.

\section{Esimerkki 6b (Vastaanotto 60)}

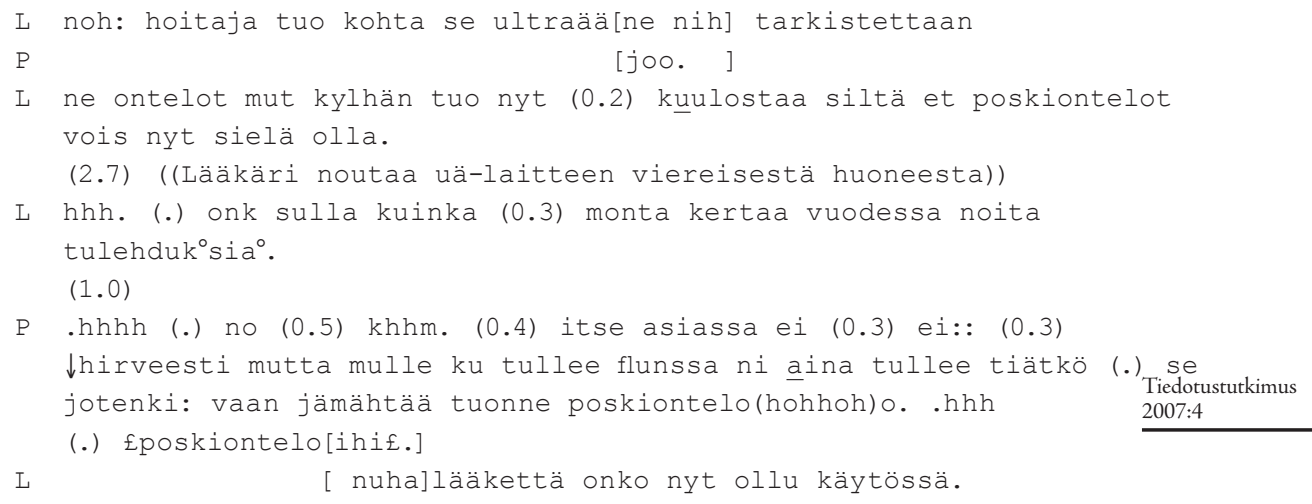


Katkelmassa lääkäri on aloittamassa poskionteloiden ultraäänitutkimusta osana fyysistä tutkimusta. Vuorossaan "tarkistettaan ne ontelot" (r.1-3) pronominin "ne" käytöllä lääkäri sitoo alkavan toimenpiteen potilaan käyntinsä syyn kuvauksessa arvelemaan poskiontelontulehdukseen. Vuoronsa toisella rakenneyksiköllä "mut kylbän tuo nyt kuulostaa siltä et poskiontelot vois nyt sielä olla" (r. 3-4) lääkäri huomioi potilaan käynnin syyn kuvauksessa arveleman diagnoosin ja antaa tälle ultraäänitutkimuksesta riippumatonta painoarvoa. Edelleen, lääkärin kysymys "onk sulla kuinka monta kertaa vuodessa noita tulebduksia" ( $r .6-7$ ) noteeraa diagnostisen arvelun ja orientoituu potilaan nykyisiin oireisiin samalla tavoin kuin potilas ne käyntinsä syyn kuvauksessa esitti.

Kun potilas esittää diagnostisen arvelun niin sanotusti upotettuna tarinaan tai oireiden listaan tarjoamatta sitä lääkärille käynnin syyn keskeisenä elementtinä, voi lääkäri ohittaa sen seuraavassa vuorossaan ja aloittaa uuden vaiheen vastaanotolla samalla tavoin kuin potilaan kertoessa vain oireet käyntinsä syyksi. Sen sijaan, että potilas toisi esiin tietoaan tai päättelyään ongelmansa luonteesta (kuten esimerkeissä 2-4), potilas asemoituu kertomaan kokemuksestaan ja upottaa diagnostisen arvelun tuon kertomuksen sisään. Tällainenkin "taka-alainen" diagnostinen arvelu luo kuitenkin vain oireista kertovan käynnin syyn kuvauksesta poikkeavan odotuksen seuraaville toiminnoilleः lääkärit palaavat siihen vastaanoton myöhemmissä vaiheissa erilaisilla viittauskäytännöillä, jotka ottavat huomioon potilaan tiedon ja episteemisen aseman.

\section{POTILAAN TIETOON ORIENTOITUMINEN LÄÄKÄRIN VASTAANOTOLLA}

Potilaan käynnin syyn kuvausta voi pitää paitsi vastauksena lääkärin avauskysymykseen (Robinson 2006; Raevaara \& Sorjonen 2001), myös avun tai palveluksen pyyntönä ja toimintakehotuksena (Ruusuvuori 2000,270-273; Whalen \& Zimmerman 1987). Potilaan käynnin syyn kuvaukset voivat toimia hyvin erityyppisinä toimintakehotuksina. Erilaisten keskustelun käytänteiden kautta potilas voi orientoitua osallistujien tiedollisiin ja institutionaalisiin asemiin eri tavoin ja ottaa erilaisia asemia suhteessa omaan toimijuuteensa ja osallistumiseensa vastaanotolla.

Vuorovaikutuksen toimintojen jäsentyminen vain oireiden kuvailu -tyyppisten vastaanottojen alussa on nähtävissä perinteisen lääkäri-potilas-suhteen kautta. Potilas orientoituu tehtäväänsä oireidensa kuvaajana, minkä jälkeen lääkärin tehtäväksi jää selvittää, mistä potilaan oireet johtuvat ja miten niitä on syytä hoitaa. Vain oireiden kuvailu -tyyppisen käynnin syyn kuvauksen jälkeen osallistujien tiedolliset asemat eivät nouse vuorovaikutuksessa esille. Näin ollen lääkärin ja potilaan suhde "lääkärikeskeisenä" tai lääkärin professionaalin aseman avulla rakentuvana vuorovaikutuksena mahdollistuu nimenomaan potilaan käynnin syyn kuvauksen relevantiksi tekemän, yhteisesti tuotetun tilannesidonnaisen ymmärryksen tuloksena (vrt. Robinson 2003).

Potilaan diagnostinen arvelu on keskustelullisena tekona erilainen kuin vain oireiden kuvailun tyyppinen käynnin syyn kuvaus. Potilas ei tuota diagnostista arvelua vain pyytääkseen lääkäriä selvittämään ongelmansa syytä, vaan myös vahvistamaan ehdotetun diagnoosin (Stivers 2002b). Tässä artikkelissa olemme tarkentaneet kuvaa potilaan diagnostisesta arvelusta keskustelullisena tekona: milloin lääkärit ottavat sen käsittelyyn välittömästi ja milloin taas siihen 
sisältyvä odotus jätetään vastaanotolla myöhemmin käsiteltäväksi (vrt. Stivers 2007, 28-50).

Potilaan tapa tuottaa diagnostinen arvelu käynnin syyn kuvauksen keskeisenä elementtinä ohjaa lääkäriä nostamaan diagnostisen arvelun ja osallistujien tiedolliset asemat käsiteltäväksi välittömästi seuraavassa puheenvuorossa. Lääkärin seuraava toiminto on sidoksissa potilaan ehdottamaan tai implikoimaan diagnoosiin. Potilas siis ottaa näin aktiivisen tiedollisen aseman suhteessa vastaanoton tehtävään. Vastaavasti lääkäri ei ainoastaan kuittaa käynnin syyn kuvausta vastaanotetuksi ja seuraavaan vaiheeseen siirtymistä ajankohtaiseksi, vaan laajentaa käynnin syyn kuvauksen jaksoa. Hän nostaa esille potilaan käynnin syyn kuvauksen erityisen merkityksen vastaanoton tehtävän ja osallistujien tiedollisten asemien muotoutumisen kannalta. Lääkäri voi nostaa käsiteltäväksi potilaan tiedon oikeellisuuden (esimerkki 2), potilaan havaintojen merkityksen (esimerkki 3) tai kuten esimerkissä 4, potilaan arvelullaan implikoiman toimintaehdotuksen. Vaikka lääkäri ottaakin huomioon potilaan näkemyksen, palauttaa hän asemansa lääketieteen asiantuntijana, kun esimerkiksi esittää tekevänsä päätelmät oman asiantuntemuksensa eikä potilaan arvelun pohjalta (kuten esimerkissä 2).

Medikaalista päättelyä sisältävät lääkärin vastattavaksi tarjotut käynnin syyn kuvaukset siis näyttävät ohjaavan osallistujien episteemisten asemien käsittelyyn, toisin kuin potilaan kertoessa vain subjektiivisesta kokemuksestaan."Heikommat" diagnostiset arvelut, jotka eräänlaisina sivuhuomautuksina eivät tarjoudu lääkärin vastattaviksi, on lääkärin mahdollista ohittaa seuraavassa vuorossaan ja ottaa käynnin syyn kuvaus vastaan samalla tavoin kuin vain oireista kertovat käynnin syyn kuvaukset. Näissäkin tapauksissa kuitenkin lääkärit vastaavat potilaan luomaan odotukseen viittaamalla diagnostisiin arveluihin vastaanoton myöhemmissä vaiheissa (esimerkit 5 ja 6). Kuten Stiversin (2002b) lapsipotilasaineistossa, myös omassa lapsi- ja aikuispotilaita käsittävässä aineistossamme lääkärit käsittelevät potilaan diagnoosiehdotusta ehdotuksen vahvistamista pyytävänä ja tiettyä hoitoa ehdottavana. Kysymykseen diagnostisen arvelun "tahattomuudesta" emme tällä tutkimuksella voi vastata. Tässä esitetty analyysi tuottaa kuitenkin lisätietoa siitä, milloin käynnin syyn kertomukseen sisältyvä diagnostinen arvelu otetaan käsittelyyn välittömästi ja milloin taas sen luoma odotus jätetään vastaanoton myöhemmissä vaiheissa käsiteltäväksi.

Huomionarvoista on, että tulosten perusteella potilaalla on käynnin syyn kuvauksessaan paikka asettaa vastaanotolle tehtävä tai "agenda" (Ruusuvuori 2000; Robinson 2003) sekä luoda odotuksia suhteessa osallistujien episteemisiin asemiin ja rooleihin näiden tehtävien toteuttajina ja institutionaalisina toimijoina (Stivers 2007). Potilaan käynnin syyn kuvaukseen sisältyy siis sekä kontrollin että auktoriteetin ulottuvuus. Aineistossa potilaan diagnoosiehdotuksen huomioiminen tai ohittaminen rakentaa lääkäreille ja potilaille erilaisia asemia toimijoina suhteessa lääketieteelliseen tietoon ja asiantuntijuuteen sekä heidän oikeuksiinsa "omistaa" tietoa. Lääkärillä on seuraavassa puheenvuorossaan tai toiminnassaan mahdollisuus vastata tai olla vastaamatta näihin odotuksiin, potilaan kuvauksen asettamissa rajoissa. Tapaukset, joissa lääkärit ottavat keskusteltavaksi potilaan esittämän diagnostisen arvion (kuvaukset, joissa potilaan diagnostinen arvelu on esitetty keskeisenä elementtinä) kertovat siitä, että lääkäri on ainakin hetkellisesti valmis joustamaan vastaanoton kulun kontrollista. Näissäkään tapauksissa lääkäri ei kuitenkaan luovuta lääketieteel- 
listä auktoriteettia potilaalle, vaan tekee tiettäväksi oman institutionaalisen asemansa lääketieteellisen tiedon haltijana.

Potilaan diagnostinen arvelu keskustelun käytäntönä nostaa esille kysymyksiä potilaan osallistumisen tavoista ja osallistujien toimijuudesta lääkärin vastaanotolla. On esitetty, että potilaat ja lääkärit orientoituvat kausaalisten päätelmien esittämiseen nimenomaisesti lääkärin tehtävänä, josta potilaat pidättäytyvät (Raevaara 2000; Gill 1998). Tässä esitetty analyysi tuo lisätietoa potilaiden ja potilaiden vanhempien käynnin syyn kuvauksista odotuksia luovana tekona (Stivers 2002b). Diagnostisen arvelun esittäminen medikaalisena päättelynä rikkoo ja problematisoi ehkä vahvimmin tavanomaisena pidettyä lääkärin ja potilaan asiantuntemuksen välistä rajaa (vrt. Mishler 1984). Se kertoo potilaan mahdollisuudesta luoda vastaanotolle juuri tietynlaisia odotuksia siitä, mikä on vastaanoton tehtävä ja vaikuttaa siihen, miten vuorovaikutus vastaanotolla etenee. Kun lääkärit vastaanottavat käynnin syyn kuvauksia ja aloittavat seuraavia toimintoja käynnin syyn kuvauksen jälkeen, he orientoituvat potilaan asettamaan agendaan.

Näin ollen yksityiskohtainen, kasvokkaisen vuorovaikutuksen analyysi voi tuoda lisää vivahteita keskusteluun potilaan osallistumisesta lääkärin vastaanotolla (Collins ym. 2007; vrt. Mead \& Bower 2000). Potilailla on valtaa, ainakin käynnin syyn kertomisen vaiheessa. Jatkotutkimuksen tehtävänä onkin kartoittaa, miten vastaanoton vuorovaikutus ja lääkärin ja potilaan tiedolliset asemat kokonaisuudessaan rakentuvat suhteessa potilaan käynnin syyn kuvaukseen: miten potilaan käyntinsä syyn kuvauksessa asettama agenda toteutuu potilaan osallisuutena ja osallistumisena vuorovaikutukseen vastaanoton myöhemmissä vaiheissa (Peräkylä ym. 2007, 139).

On mahdollista, että tässä tutkimuksessa käytetty rajaus ylähengitystie- ja korvatulehduskäynteihin tuottaa potilaan osallistumisesta kuvan, joka ei sellaisenaan pätisi esimerkiksi pitkäaikaissairauksien seurantaan ja hoitoon liittyvillä vastaanotoilla. Jatkotutkimuksessa olisikin mahdollista laajentaa tarkastelua vertailuaineistoon, jossa ongelmien luonne on selvästi erityyppinen. Esitetty havainto luo mahdollisuuksia myös pitkittäistutkimukselle. Olisi mahdollista tarkastella käynnin syyn kertomisen tapoja ja niitä seuraavaa lääkärin toimintaa olemassa olevissa aiemmin nauhoitetuissa ${ }^{4}$ sekä mahdollisesti myöhemmin nauhoitettavissa lääkärinvastaanotoissa edellä esitetystä näkökulmasta. Näin voitaisiin tutkia terveystiedon lisääntymisen ja saatavuuden parantumisen yhteyttä potilaiden diagnostisten arveluiden esiintymiseen ja niihin vastaamisen tavoissa tapahtuvaan mahdolliseen muutokseen. Yksityiskohtainen vuorovaikutuksen analyysi antaa välineitä potilaan asemassa ja aktiivisessa osallistumisessa tapahtuneiden muutosten tutkimiseen. 
1 Analyysin ulkopuolelle jäi 12 potilaan vastaanotot, joilla käynnin syyn kuvaus ei ole tallentunut nauhalle tai joilla vastaanotto on uusintakäynti. Tällöin käynnin syyn kertomisen jakso on erilainen.

245 käynnin syyn kuvausta eli $52 \%$ tutkimuksen aineistosta.

3 Aineistossa on kaksi vastaanottoa, joilla lääkäri ei viittaa potilaan/potilaan vanhemman diagnostiseen arveluun vastaanoton myöhemmissä vaiheissa tilannetekijöiden vuoksi (potilaan vaiva osoittautuu joksikin muuksi kuin ylähengitystieinfektiosta johtuvaksi). Näitä vastaanottoja ei ole tässä yhteydessä mahdollista käsitellä.

4 Kirjoittajien käytössä on vuosina 1991-1992 sekä 1999 nauhoitettuja yleislääkärin vastaanottoja.

\section{Kirjallisuus}

Beckman, Howard \& Richard Frankel (1984) The effect of physician behaviour on the collection of data. Annals of Internal Medicine 101, 692-696.

Barry, Christine; Fiona Stevenson; Nicky Britten; Nick Barber \& Colin Bradley (2001) Giving voice to the lifeworld. More humane, more effective medial care? A qualitative study of doctor-patient communication in general practice. Social Science \& Medicine 53: 487-505.

Collins, Sarah (tulossa) 'Right... okay': a health professionals' practice for focusing in on the business of the consultation.

Collins, Sarah; Nicky Britten; Johanna Ruusuvuori \& Andrew Thompson (2007) Understanding the process of patient participation. Teoksessa Collins, Sarah; Britten, Nicky; Ruusuvuori, Johanna \& Thompson, Andrew (toim.) Patient Participation in Health Care Consultations. Qualitative Perspectives. Berkshire, McGraw-Hill, Open University Press.

Davis, Kathy (1988) Power under the microscope. Foris, Dordrecht.

Drew, Paul (2006) Misalignments in "after-hours" calls to a British GP's practice: a study in telephone medicine. Teoksessa Heritage, John \& Maynard, Douglas W (toim.) Communication in Medical Care. Interaction between primary care physicians and patients. Cambridge, Cambridge University Press.

Drew, Paul (2001) Spotlight on the patient. Text 21(1/2): 261-269.

Fisher, Sue (1991) A discourse of the social: medical talk/power talk/ oppositional talk? Discourse \& Society 2: 157-182.

Gill, Virginia (1998) Doing attributions in medical interaction: Patients' explanations for illness and doctors' responses. Social Psychology Quarterly 61(4): 342-360.

Halkowski, Timothy (2006) Realizing the illness: patients' narratives of symptoms discovery. Teoksessa Heritage, John \& Maynard, Douglas W (toim.) Communication in Medical Care. Interaction between primary care physicians and patients. Cambridge, Cambridge University Press.

Heritage, John (1984) Garfinkel and Ethnomethodology. Cambridge, Polity Press.

Heritage, John \& Douglas W Maynard (2006) Introduction: Analyzing interaction between doctors and patients in primary care encounters. Teoksessa Heritage, John \& Maynard, Douglas W (toim.) Communication in Medical Care. Interaction between primary care physicians and patients. Cambridge, Cambridge University Press.

Heritage, John \& Jeffrey Robinson (2006) Accounting for the visit: giving reason for seeking medical care. Teoksessa Heritage, John \& Maynard, Douglas W (toim.) Communication in Medical Care. Interaction between primary care physicians and patients. Cambridge, Cambridge University Press.

Heritage, John \& Geoffrey Raymond (2005) The terms of agreement: indexing epistemic authority and subordination in assessment sequences. Social Psychology Quarterly 68:1:1538.

Heritage, John \& Tanya Stivers (1999) Online commentary in acute medical visits: a method of shaping patient expectations. Social Science \& Medicine 49: 1501-1517.

Jefferson, Gail (1984) Transcript notation. Teoksessa Atkinson, J Maxwell \& Heritage, John (toim.) Structures of Social Action: Studies in conversation analysis. Cambridge, Cambridge University Press.

Jefferson, Gail (1985) On the interactional unpackaging of a 'gloss'. Language in Society 14: 435-366. 
Keinänen-Kiukaanniemi, Sirkka \& Marjukka Mäkelä (1991) Työn hallinta. Teoksessa E. Kumpusalo, M. Ellonen, S. Keinänen-Kiukaanniemi ja K. Mattila, Duodecim, Helsinki, 69-135.

Lukes, Steven (1978). Power and authority. Teoksessa T. Bottomore and R. Nisbet (toim.) A history of sociological analysis. Heinemann, London, 633-676.

Mangione-Smith, Rita; Elizabeth McGlynn; Marc Elliott; Paul Krogstad \& Robert Brook (1999) The relationship between perceived parental expectations and pediatrician antimicrobial prescribing behaviour. Pediatrics 103(4): 711-717.

Mead, Nicola \& Peter Bower (2000) Patient-centredness: a conceptual framework and review of the empirical literature. Social Science \& Medicine 51: 1087-1110.

Mishler, Elliot (1984) The discourse of medicine: Dialectics of medical interviews. New Jersey, Ablex.

Ong, L+; J.D. de Haes; A. Hoos \& F. Lammes (1995) Doctor-patient communication: a review of the literature. Social Science and Medicine 40(7): 903-918.

Pendleton, David (1983) Doctor-patient communication: a review. Teoksessa Pendleton, David (toim.) Doctor-patient communication. Academic, New York, 5-53.

Peräkylä, Anssi (1998) Authority and accountability: The delivery of diagnosis in primary health care. Social Psychology Quarterly 61:301-320.

Peräkylä, Anssi (1997) Conversation analysis: a new model of research in doctor-patient communication. Journal of the Royal Society of Medicine 90: 205-208.

Peräkylä, Anssi \& David Silverman (1991) Owning experience. Describing the experience of other persons. Text 11(3): 441-480.

Peräkylä, Anssi \& Johanna Ruusuvuori (2007) Components of participation in health care consultations. A conceptual model for research. Teoksessa Collins, Sarah; Britten, Nicky; Ruusuvuori, Johanna \& Andrew Thompson (toim.) Patient Participation in Health Care Consultations. Qualitative Perspectives. Berkshire, McGraw-Hill, Open University Press.

Peräkylä, Anssi; Johanna Ruusuvuori \& Pirjo Lindfors (2007) What is patient participation? Reflections arising from the study of general practice, homeopathy and psychoanalysis. Teoksessa Collins, Sarah; Britten, Nicky; Ruusuvuori, Johanna \& Thompson, Andrew (toim.) Patient Participation in Health Care Consultations. Qualitative Perspectives. Berkshire, McGraw-Hill, Open University Press.

Pomerantz, Anita (1980) Telling my side: 'limited access' as a 'fishing' device. Sociological Inquiry 50: 186-98.

Raevaara, Liisa (2000) Potilaan diagnoosiehdotukset lääkärin vastaanotolla. Keskustelunanalyyttinen tutkimus potilaan institutionaalisista tehtävistä. Helsinki, SKS.

Raevaara, Liisa \& Marja-Leena Sorjonen (2001) Lääkärin kysymykset ja potilaan vastaukset. Teoksessa Sorjonen, Marja-Leena, Peräkylä, Anssi \& Eskola, Kari (toim.) Keskustelu lääkärin vastaanotolla. Tampere, Vastapaino.

Robinson, Jeffrey (2006) Soliciting patients' presenting concerns. Teoksessa Heritage, John \& Maynard, Douglas W (toim.) Communication in Medical Care. Interaction between primary care physicians and patients. Cambridge, Cambridge University Press.

Robinson, Jeffrey (2003) An Interactional Structure of Medical Activities During Acute Visits and Its Implications for Patients' Participation. Health Communication 15(1): 27-59.

Robinson, Jeffrey (2001) Closing medical encounters: two physician practices and their implications for the expression of patients' unstated concerns. Social Science \& Medicine 53: 639-656.

Robinson, Jeffrey \& John Heritage (2006) Physicians' opening questions and patients' satisfaction. Patient Education and Counselling 60: 279-285.

Robinson, Jeffrey \& Tanya Stivers (2001) Achieving activity transitions in physician-patient encounters. From history taking to physical examination. Human Communication Research 27(2): 253-298.

Ruusuvuori, Johanna (2005) Comparing homoeopathic and general practice consultations: the case of problem presentation. Communication \& Medicine 2(2): 123-136.

Ruusuvuori, Johanna (2001) Looking means listening: Coordinating displays of engagement in doctor-patient interaction. Social Science \& Medicine 52(7): 1093-1108.

Ruusuvuori, Johanna (2000) Control in Medical Consultation. Practices of Giving and Receiving the Reason for the Visit in Primary Health Care. Acta Universitatis Tamperensis 16.

Sacks, Harvey; Emanuel A Schegloff \& Gail Jefferson (1974) A simplest systematics for the organization of turn-taking for conversation. Language 50: 696-735. 
Schegloff, Emanuel A (2007) Sequence Organization in Interaction: A Primer in Conversation Analysis. Vol. 1. Cambridge, Cambridge University Press.

Schegloff, Emanuel A \& Harvey Sacks (1973) Opening up closings. Semiotica 7: 289-327.

Sorjonen, Marja-Leena (2001) Responding in Conversation. A study of response particles in Finnish conversation. Amsterdam, Benjamins.

Stivers, Tanya (2007) Prescribing under Pressure. Parent-Physician Conversations and Antibiotics. Oxford Studies in Sociolinguistics. New York, Oxford University Press.

Stivers, Tanya (2002a) Participating in decisions about treatment: Overt parent pressure for antibiotic medication in pediatric encounters. Social Science \& Medicine 54: 1111-1130.

Stivers, Tanya (2002b) Presenting the Problem in Pediatric Encounters: "Symptoms Only" Versus "Candidate Diagnosis" Presentations. Health Communication 14(3): 299-338.

Toiviainen, Hanna (2007) Konsumerismi, potilaiden ja kuluttajien aktiivinen toiminta sekä erityisesti lääkäreiden kokemukset ja näkemykset potilaista kuluttajina. STAKES.

Whalen, Marilyn \& Don Zimmerman (1987) Sequential and Institutional Contexts in Calls for Help. Social Psychology Quarterly 50(2): 172-185.

\section{Liite Litterointisymbolit}

? Nouseva vuoronloppuinen intonatio

, Tasainen vuoronloppuinen intonaatio

joo. $\quad$ Laskeva/päättävä vuoronloppuinen intonaatio

joo Sisäänhengittäessä lausuttu sana/tavu/äänne

$\downarrow \quad$ Ympäröivää puhetta matalammalta lausuttu sana/tavu/äänne

$\uparrow \quad$ Ympäröivää puhetta korkeammalta lausuttu sana/tavu/äänne

\# \# "Nariseva” ääni

: $\quad$ Edeltävän äänteen venytys

$<\quad$ Hitaasti lausuttu sana/tavu

$>\quad$ Nopeasti lausuttu sana/tavu

.hh Sisäänhengitys

hh Uloshengitys

sana Painotettu sana/tavu/äänne

[sa ]na Päällekkäispuhunnan alku ja loppu

sana $<\quad$ "Katkaistu" sana/tavu/äänne

(.) Mikrotauko, $<0.2 \mathrm{~s}$

(1.2) Tauko sekunnin ja kymmenysten tarkkuudella

$=\quad$ Välittömästi edellisen vuoron jälkeen alkava puhe

$\circ$ Hiljaisella äännellä lausuttu sana/tavu/äänne

sanah Uloshengityksen aikana lausuttu sana/tavu/äänne, uloshengitys sanan lopussa

(( )) Litteroijan merkinnät 